\title{
Response of Sweet Wormwood (Artemisia annua L.) to Different Rates of Inorganic Nitrogen Fertilizer in Semi-Arid Zimbabwe
}

\author{
John Nyoni1, Tendai Madanzi², Joanah Midzi², Tavagwisa Muziri², Arnold Kapenzi ${ }^{3}$ \\ ${ }^{1}$ Rio Tinto Agricultural College, Kadoma, Zimbabwe \\ ${ }^{2}$ Agronomy Department, Midlands State University, Gweru, Zimbabwe \\ ${ }^{3}$ Land and Water Resources Management Department, Midlands State University, Gweru, Zimbabwe \\ Email: jtmidzi@gmail.com
}

How to cite this paper: Nyoni, J., Madanzi, T., Midzi, J., Muziri, T. and Kapenzi, A. (2020) Response of Sweet Wormwood (Artemisia annua L.) to Different Rates of Inorganic Nitrogen Fertilizer in Semi-Arid Zimbabwe. American Journal of Plant Sciences, 11, 529-537.

https://doi.org/10.4236/ajps.2020.114037

Received: May 28, 2015

Accepted: April 5, 2020

Published: April 8, 2020

Copyright $\odot 2020$ by author(s) and Scientific Research Publishing Inc. This work is licensed under the Creative Commons Attribution International License (CC BY 4.0).

http://creativecommons.org/licenses/by/4.0/

\begin{abstract}
Sweet wormwood (Artemisia annua L.) is a highly valued crop, native to China, whose active ingredient "artemisinin" and its derivatives: artemether and artesunate, are used to prepare anti-malaria drugs. In Zimbabwe, very little has been done on improving agronomic practices that can enhance the yield of this crop. As a result, herbal gardens in Zimbabwe producing this sweet aromatic herb are realizing low leaf biomass. The objective of this study was to determine the effects of varying nitrogen fertilizer levels on growth and yield of Artemisia annua. A randomized complete block design (RCBD) was used and replicated four times. The fertilizer treatments consisted of 0,40 $\mathrm{kg} \mathrm{N} / \mathrm{ha}, 80 \mathrm{~kg} \mathrm{~N} / \mathrm{ha}, 120 \mathrm{~kg} \mathrm{~N} / \mathrm{ha}, 160 \mathrm{~kg} \mathrm{~N} / \mathrm{ha}$ and were applied as a top dress four weeks after planting. Applying $80 \mathrm{~kg} \mathrm{~N} / \mathrm{ha}, 120 \mathrm{~kg} \mathrm{~N} / \mathrm{ha}$ or $160 \mathrm{~kg}$ $\mathrm{N} / \mathrm{ha}$ resulted in the best performance of Artemisia annua with respect to the plant height, root dry weight, stem dry weight and leaf biomass. Low $\mathrm{N}$ level (40 kg N/ha) recorded significantly low means in plant height, root weight, stem weight and leaf biomass. The results suggest that $80 \mathrm{~kg} \mathrm{~N} /$ ha should be recommended for use by Artemisia annua farmers, since there was no significant different among the three higher fertilizer levels. However there is need for further research to determine different fertilizer use efficient to come up with accurate agronomic data package for Zimbabwean farmers.
\end{abstract}

\section{Keywords}

Artemisia annua, Artemisinin, Nitrogen Fertilizer, Yield, Semi-Arid

\section{Introduction}

Artemisia annua L., commonly known as Sweet wormwood, Sweet Annie or 
qinghao, is an annual aromatic shrub native to China and has been used for both ornamental and medicinal purposes for over two millennia [1] [2] [3]. The genus Artemisia belongs to the Compositae family which includes well-known plants used in medicine, perfumery and the food and drink industry [4] [5]. It is now cultivated globally as the only source of a potent anti-malarial drug, artemisinin [6] [7] [8]. Its Artemisinin extract has proved effective in the onslaught against the highly adaptable malaria parasite which has become resistant to many other anti-malarials [9] [10] [11] [12]. The compound is isolated from the leaves, stem buds, flowers and seeds. However most of the artemisinin is stored in the glandular trichomes on the leaves' epidermis [13] [14] [15]. Malaria is a devastating global health crisis, with an estimated 300 million people succumbing to infection by the malaria parasite annually [9]. A greater majority of cases have been reported in sub-Saharan Africa, with between 500,000 and 2.5 million people dying each year from the disease and children represent a larger fraction of the victims [10].

The sweetly aromatic herb is highly adaptive to both temperate and non-temperate regions of the world. The cultivation of $A$. annua represents an important opportunity to rural communities in Zimbabwe, as a source of affordable medicine and as a source of income [16]. Despite the high efficacy of artemisinin-based malaria treatment, its demand currently surpasses the available supply from farmers growing sweet wormwood [17] [18]. This shortage is attributed to low leaf yield due to poor crop management practices [19]. Optimum supply of nutrients in $A$. annua production improves growth rate, yield and quality of sweet wormwood [20]. Only a few trials have been done on $A$. annua fertilisation in Zimbabwe. Studies conducted at Moi University in Kenya have shown that low level of nitrogen, that is; $40 \mathrm{~kg} \mathrm{~N} / \mathrm{ha}$, has no effect on growth and yield of $A$. annua while $80 \mathrm{~kg} \mathrm{~N} / \mathrm{ha}$ g or $120 \mathrm{~kg} \mathrm{~N} / \mathrm{ha}$ [19]. In South Africa, fertilisation recommendations made from work done in Australia are being used. Trials indicated that plants reacted well to Nitrogen phosphate and potash applied at $60 \mathrm{~kg} \mathrm{~N} / \mathrm{ha}$ and $60 \mathrm{~kg} \mathrm{P} / \mathrm{ha}$ and $50 \mathrm{~kg} \mathrm{~K} / \mathrm{ha}$. Organic compost supplied at 3 - $5 \mathrm{t} / \mathrm{ha}$ gave good results [21] [22] [23].

The use of inorganic fertilizers in the cultivation of $A$. annua is therefore investigated in this study to come up with optimum production practices in Semi-arid Zimbabwe in order to promote its cultivation and use.

\section{Materials and Methods}

\subsection{Description of Study Site}

The experiment was carried out at Rio Tinto Agricultural College, Empress Mine in Kwekwe district, Midlands Province of Zimbabwe. The grid for the site is $29^{\circ} 25^{\prime \prime} \mathrm{E}$ and $18^{\circ} 35^{\prime \prime} \mathrm{S}$ and it is in Natural Region III (NRIII) of Zimbabwe. The region receives an average annual rainfall of $674 \mathrm{~mm}$ which extends from November to February. The average temperature for the site is $24^{\circ} \mathrm{C}$ and is elevated $1200 \mathrm{~m}$ above sea level. The site has characteristic sandy loams belonging to the 
fersialitic group with kaolinite clay minerals dominant in the soils [24]. The soil $\mathrm{pH}$ is 6.5.

\subsection{Experimental Design and Treatments}

A randomized complete block design (RCBD) was used, with four replications, with the slope as a blocking factor. The treatments were five different nitrogen levels applied to the plots in the form of ammonium nitrate (Table 1). Slope was the blocking factor.

\subsection{Research Procedure}

The experiment was carried out in four blocks, with each treatment having four plots. Trial plots were planted after the first effective rains, and were rain fed throughout the growing season. Each field block had a total of 20 plots for the 5 treatments. Each plot had a net size of $2 \mathrm{~m} \times 2 \mathrm{~m}$ with 12 planting stations. The seeds were planted at an inter row spacing of $300 \mathrm{~mm} \times 900 \mathrm{~mm}$. A pinch of seeds were dropped at a planting station and covered with sandy soil. No basal fertilizer was used during planting. Two weeks after emergence, thinning was carried out to achieve a plant population of 37,000 plants per hectare. Weeds were kept under control during the early stages of growth by hand hoeing. Fertilizer, Ammonium nitrate, was applied to each plot according to the treatment structure. No insect pests and diseases were observed. After 57 days the plants were harvested.

\subsection{Data Collection and Analysis}

A random sampling of 12 plants per plot was done for data collection. Data collected included plant height, root dry weight, stem weight and leaf biomass. Plant height was determined on a weekly basis. The other parameters were determined at the end of the project cycle, at 57 days after planting. A destructive method was used to determine the root, stem and biomass of the sweet wormwood plants by pulling them off the ground. Samples were placed under a plant press and allowed to dry.

Data on plant height, leaf biomass and total dry matter was statistically analysed using Analysis of variance (ANOVA) using GenStat 14 version software. Treatment means were compared by the Least Significant Difference (LSD) at $5 \%$ significance level.

Table 1. Table of treatments.

\begin{tabular}{cc}
\hline Treatment number & Inorganic fertilizer application rate $(\mathrm{kg} \mathrm{N} / \mathrm{ha})$ \\
\hline 1 & 0 \\
2 & 40 \\
3 & 80 \\
4 & 120 \\
5 & 160 \\
\hline
\end{tabular}




\section{Results}

\subsection{Effects of Different Nitrogen Fertilizer Rates on Plant Height of A. annua}

There was no significant difference among treatments during the third and fourth weeks on plant height due to different nitrogen fertilizer rates $(\mathrm{P}>0.05)$ (Table 2). Significant differences among treatments due to application of different nitrogen fertilizers rates were only observed at week 5 to week 8 ( $\mathrm{P}<$ 0.05). At week 5 there were no statistical differences between treatments with 0 and $40 \mathrm{~kg} \mathrm{~N} / \mathrm{ha}$ which gave the lowest plant heights of $23.77 \mathrm{~cm}$ and $25.47 \mathrm{~cm}$ respectively. The highest plant height was observed at $80 \mathrm{~kg} \mathrm{~N} / \mathrm{ha}, 120 \mathrm{~kg} \mathrm{~N} / \mathrm{ha}$ and $160 \mathrm{~kg} \mathrm{~N} / \mathrm{ha}$ which showed no statistical differences and gave heights of $31.23 \mathrm{~cm}, 34 \mathrm{~cm}$ and $35.57 \mathrm{~cm}$ respectively. At week 6, there were no statistical differences at 0 and $40 \mathrm{~kg} \mathrm{~N} / \mathrm{ha}$ with plants heights of 26.13 and $28.97 \mathrm{~cm}$ respectively. Highest plant heights were observed at rates of $120 \mathrm{~kg} \mathrm{~N} / \mathrm{ha}$ and 180 $\mathrm{kg} \mathrm{N} / \mathrm{ha} ; 47.23$ and 48.17 respectively, which were not statistically different. At 7 weeks, the lowest plant height was recorded for $0 \mathrm{~kg} \mathrm{~N} / \mathrm{ha}$ with $29.6 \mathrm{~cm}$. The highest plant was observed at $120 \mathrm{~kg} \mathrm{~N} / \mathrm{ha}$ and $160 \mathrm{~kg} \mathrm{~N} / \mathrm{ha}$ with 60.9 and 65.5 $\mathrm{cm}$ respectively. At week 8 , all treatments showed significant differences, however, treatments with $120 \mathrm{~kg} \mathrm{~N} / \mathrm{ha}$ and $160 \mathrm{~kg} \mathrm{~N} / \mathrm{ha}$ were not statistically different. The highest plant heights were observed at the latter rates with 73.4 and 75.6 $\mathrm{cm}$ plant heights respectively.

\subsection{Effects of Different Nitrogen Fertilizer Rates on Root Dry Weight $A$. annua}

There were significant differences among treatments on the root dry weight $(\mathrm{P}<$ 0.05) (Figure 1). There were no statistical differences between treatment with 0 and $40 \mathrm{~kg} \mathrm{~N} / \mathrm{ha}$ which had root dry weight of $1.03 \mathrm{~g}$ and $1.07 \mathrm{~g}$ respectively. The highest root dry matter was obtained in plots treated with $160 \mathrm{~kg} \mathrm{~N} / \mathrm{ha}$ and had a mean root dry weight of $26.5 \mathrm{~g}$.

Table 2. Effects of different nitrogen fertilizer rates on plant height (Plant height $(\mathrm{cm})$ ).

\begin{tabular}{ccccccc}
\hline $\begin{array}{c}\text { Fertilizer } \\
\text { application rate } \\
(\mathrm{kg} / \mathrm{ha})\end{array}$ & 3WAE & 4WAE & 5WAE & 6WAE & 7WAE & 8WAE \\
\hline 0 & $8.167^{\mathrm{a}}$ & $17.5^{\mathrm{a}}$ & $23.77^{\mathrm{a}}$ & $26.13^{\mathrm{a}}$ & $29.6^{\mathrm{a}}$ & $31.5^{\mathrm{a}}$ \\
40 & $8.167^{\mathrm{a}}$ & $17.53^{\mathrm{a}}$ & $25.47^{\mathrm{ab}}$ & $28.97^{\mathrm{a}}$ & $42.8^{\mathrm{b}}$ & $46.2^{\mathrm{b}}$ \\
80 & $8.167^{\mathrm{a}}$ & $16.57^{\mathrm{a}}$ & $31.23^{\mathrm{bc}}$ & $38.13^{\mathrm{b}}$ & $54.2^{\mathrm{c}}$ & $58.9^{\mathrm{c}}$ \\
120 & $8.133^{\mathrm{a}}$ & $17^{\mathrm{a}}$ & $34^{\mathrm{c}}$ & $47.23^{\mathrm{c}}$ & $60.9^{\mathrm{cd}}$ & $73.4^{\mathrm{d}}$ \\
160 & $8.2^{\mathrm{a}}$ & $17^{\mathrm{a}}$ & $35.57^{\mathrm{c}}$ & $48.17^{\mathrm{c}}$ & $65.5^{\mathrm{d}}$ & $75.6^{\mathrm{d}}$ \\
Grand mean & 8.167 & 17.12 & 30.01 & 37.73 & 50.6 & 57.1 \\
F pr & 1 & 0.976 & 0.008 & $<0.001$ & $<0.001$ & $<0.001$ \\
LSD & 0.7198 & 3.992 & 6.186 & 6.211 & 8.11 & 7.44 \\
CV \% & 4.7 & 12.4 & 10.9 & 8.7 & 8.5 & 6.9 \\
\hline
\end{tabular}




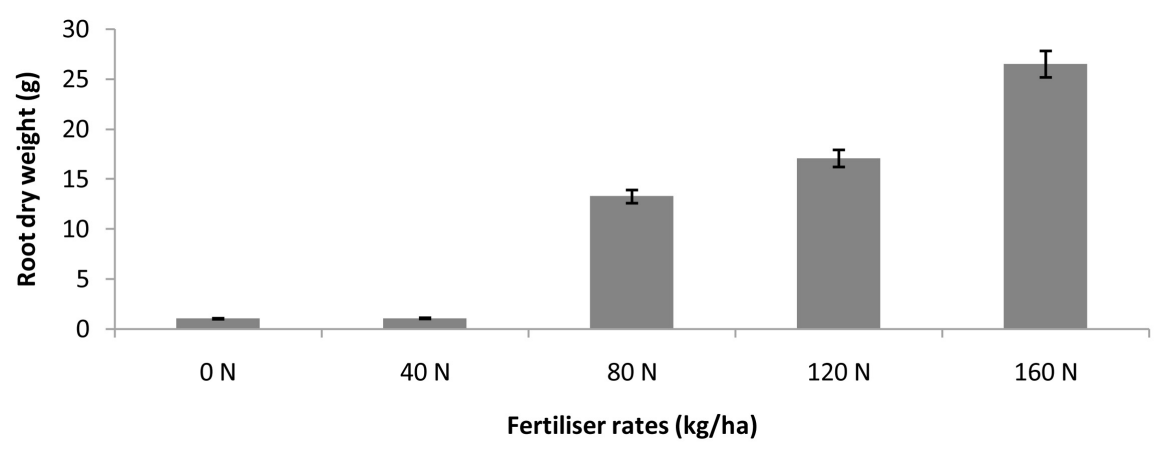

Figure 1. Effects of fertilizer rates on root dry weight of $A$. annua.

\subsection{Effect of Inorganic Nitrogen Fertilizer Application on Stem Weight of $A$. annua}

There were significant differences among treatments $(\mathrm{P}<0.05)$, for all plots except for the plots applied $40 \mathrm{~kg} \mathrm{~N} / \mathrm{ha}$ and $80 \mathrm{~kg} \mathrm{~N} / \mathrm{ha}$ which were not statistically different (Table 3). The highest stem weight was obtained in plots applied 160 $\mathrm{kg} \mathrm{N} / \mathrm{ha}$ with mean weight of $31.33 \mathrm{~g}$. The lowest was recorded for $\mathrm{O} \mathrm{kg} \mathrm{N} / \mathrm{ha}$ which recorded $2.14 \mathrm{~g}$.

\subsection{Effects of Fertilizer Rates on Leaf Biomass of A. annua}

There were significant differences in leaf biomass among treatments $(\mathrm{P}<0.05)$ (Figure 2). The lowest leaf biomass was recorded at $0 \mathrm{~kg} \mathrm{~N} / \mathrm{ha}$ and $40 \mathrm{~kg} \mathrm{~N} / \mathrm{ha}$ which recorded mean biomass of $0.55 \mathrm{~g}$ and $5.46 \mathrm{~g}$ respectively. Leaf biomass was observed to increase from $80 \mathrm{~kg} \mathrm{~N} / \mathrm{ha}$ up to $160 \mathrm{~kg} \mathrm{~N} / \mathrm{ha}$, of which no statistical differences were among those 3 treatment rates. At $80 \mathrm{~kg} \mathrm{~N} / \mathrm{ha}, 120 \mathrm{~kg} \mathrm{~N} / \mathrm{ha}$ and $160 \mathrm{~kg} \mathrm{~N} / \mathrm{ha}$ the leaf biomass were 10.13, 11.94 and $14.34 \mathrm{~g}$ respectively.

\section{Discussion}

\subsection{Effects of Nitrogen Fertilizer on the Mean Stem Height of A. annua}

There was a gradual increase in stem height as time (weeks) progressed. Observations made after week 5 showed that rates of $80 \mathrm{~kg} \mathrm{~N} / \mathrm{ha}, 120 \mathrm{~kg} \mathrm{~N} / \mathrm{ha}$ and 160 $\mathrm{kg} \mathrm{N} /$ ha applied were characterised by increased plant height compared to other treatments. This was also observed in the work done by Kinerk (1984) [24] and it was mentioned that nitrogen promotes shoot and leaf growth. As the rate of nitrogen fertilizer increased, a corresponding increase in the mean height of $A$. annua was observed. Possibly the stunting noted in plots with $0 \mathrm{~kg} \mathrm{~N} / \mathrm{ha}$ and the lower rates of $\mathrm{N}$ accounted for the stunted growth which subsequently contributed to low mean height of $A$. annua. Nitrogen is a key constituent of chlorophyll and proteins and is essential for leaf initiation and plant growth which resulted in a well pronounced height of plants in plots treated with $160 \mathrm{~kg} \mathrm{~N} / \mathrm{ha} . A$. annua has been reported to grow up to the range of $30-100 \mathrm{~cm}$ [3] [4] [23]. In this research the least height was $31.5 \mathrm{~cm}$ (at $0 \mathrm{~N} \mathrm{~kg} / \mathrm{ha}$ ) and the highest was 75.6 $\mathrm{cm}$ (at $160 \mathrm{~kg} \mathrm{~N} / \mathrm{ha}$ ). An increase in the rate of application of nitrogen fertilizer 
Table 3. Effect of inorganic nitrogen fertilizer application on stem weight of $A$. annua at harvesting time.

\begin{tabular}{cc}
\hline Fertilizer application rate $(\mathrm{kg} / \mathrm{ha})$ & Stem weight $(\mathrm{g})$ \\
\hline $0 \mathrm{~N}$ & $2.14^{\mathrm{a}}$ \\
$40 \mathrm{~N}$ & $9.24^{\mathrm{b}}$ \\
$80 \mathrm{~N}$ & $13.6^{\mathrm{b}}$ \\
$120 \mathrm{~N}$ & $24^{\mathrm{c}}$ \\
$160 \mathrm{~N}$ & $31.33^{\mathrm{d}}$ \\
Grand mean & 16.08 \\
F pr & 0.001 \\
LSD & 5.926 \\
CV $\%$ & 19.6 \\
\hline
\end{tabular}

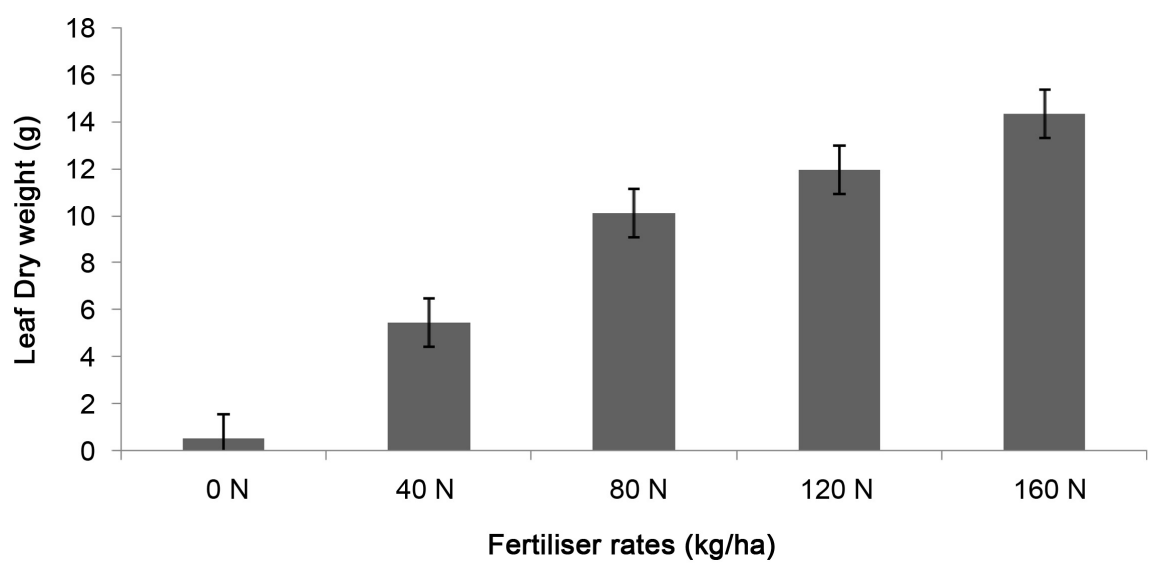

Figure 2. Effects of fertilizer rates on leaf biomass.

results in vigorous vegetative growth [25].

\subsection{Effects of Nitrogen Fertilizer on the Mean Root Weight of A. annua}

As the rate of nitrogen fertilizer increased, there was a corresponding increase in the mean root weight of $A$. annua. The low root dry weight observed in treatments with low $\mathrm{N}$ rates corresponded with a general stunted growth and low yield across all treatments. Plots treated with 0 and $40 \mathrm{~kg} \mathrm{~N} / \mathrm{ha}$ had the least root dry weight. Application rates of $80 \mathrm{~kg} \mathrm{~N} / \mathrm{ha}, 120 \mathrm{~kg} \mathrm{~N} / \mathrm{ha}$ and $160 \mathrm{~kg} \mathrm{~N} / \mathrm{ha}$ increased the mean root weight of $A$. annua and these were characterised by vigorous vegetative growth of $A$. annua, rapid leaf development and development of large frame leaves. An increase in the rate of nitrogen fertilizer resulted in a corresponding increase in both mean heights and mean root weight of $A$. annua. In the present study, optimum $\mathrm{N}$ fertilization had a favorable impact on root growth, which is supported by previous findings that $\mathrm{N}$ availability has significant effects on root biomass, production, and mortality [26]; root elongation [27]; and higher root-order development and branching [28]. 


\subsection{Effects of Nitrogen Fertilizer on the Mean Yield (Leaf Biomass) of A. annua}

The mean yield from the plots treated with $80 \mathrm{~kg} \mathrm{~N} / \mathrm{ha}$ increased significantly, but remained the same for those plots treated with $120 \mathrm{~kg} \mathrm{~N} / \mathrm{ha}$ and $160 \mathrm{~kg} \mathrm{~N} / \mathrm{ha}$. This can be explained by the fact that in plots treated with $80 \mathrm{~kg} \mathrm{~N} / \mathrm{ha}$ there was an increase in branching of $A$. annua crop. In addition, the results from the Moi University Chepkoiled campus in Kenya suggested that the optimum nitrogen level for growth of $A$. annua is $80 \mathrm{~kg} \mathrm{~N} /$ ha that resulted in increased plant height, branching and overall fresh leaf yield. On the other hand, WHO (2007) [29] recommended $120 \mathrm{~kg} \mathrm{~N} / \mathrm{ha}$. A slight increase in $A$. annua yield was observed in plots treated with $160 \mathrm{~kg} \mathrm{~N} / \mathrm{ha}$. Nitrogen promotes the development of large frame leaves hence higher yield. With the results from the harvested components, it is suggested that where the application is limited, $80 \mathrm{~kg} \mathrm{~N} / \mathrm{ha}$ instead of $120 \mathrm{~kg} \mathrm{~N} / \mathrm{ha}$ and $160 \mathrm{~kg} \mathrm{~N} / \mathrm{ha}$ is opted for since there is no statistical difference among the three fertilizer levels.

There was significant difference on dry matter root weight. There was no significance difference between treatments $0 \mathrm{~kg} \mathrm{~N} / \mathrm{ha}$ and $40 \mathrm{~kg} \mathrm{~N} / \mathrm{ha}$. There was no significance difference between plots treated with $0 \mathrm{~kg} \mathrm{~N} / \mathrm{ha}$ and $40 \mathrm{~kg} \mathrm{~N} / \mathrm{ha}$ in mean root weight of $A$. annua. The highest root dry matter was obtained in plots treated with $160 \mathrm{~kg} \mathrm{~N} / \mathrm{ha}$. A notable increase in stem weight was observed in treatments which $160 \mathrm{~kg} \mathrm{~N} / \mathrm{ha}$ of nitrogen fertilizer was applied. Although at 40 $\mathrm{kg} \mathrm{N} / \mathrm{ha}$ there was appreciable above ground dry matter compared to the control, the same was not observed with below ground dry matter (roots). This had physiological implications on subsequent weekly growth as shown in Table 2.

As the rate of application of nitrogen fertilizer increased, a corresponding increase in the harvested component was observed. The control (0 kg N/ha) had the lowest mean yield as no nitrogen was applied. The mean yield from the plots treated with $40 \mathrm{~kg} \mathrm{~N} / \mathrm{ha}$ increased as compared to the control as $40 \mathrm{~kg} \mathrm{~N} / \mathrm{ha} \mathrm{ni-}$ trogen fertilizer was applied and showed evidence that nitrogen also promotes shoots and leaf growth [24]. Fertilizer rates; $80 \mathrm{~kg} \mathrm{~N} / \mathrm{ha}, 120 \mathrm{~kg} \mathrm{~N} / \mathrm{ha}$ and $160 \mathrm{~kg}$ $\mathrm{N} / \mathrm{ha}$, gave a significantly high yield. However yield from these rates were not significantly different to each other.

\section{Conclusion and Recommendations}

Although the compound artemisinin is isolated from the leaves, stem buds, flowers and seeds it is reported that the leaves are principal source in commercial operations since they contain by far the most artemisinin by mass. From this study, the leaf biomass becomes the most important parameter and fertiliser rates of $80 \mathrm{~kg} \mathrm{~N} / \mathrm{ha}, 120 \mathrm{~kg} \mathrm{~N} / \mathrm{ha}$ and $160 \mathrm{~N} \mathrm{~kg} /$ ha gave the highest yield. Because no significant differences were observed among these three rates, it can be suggested that where fertiliser application is limited, $80 \mathrm{~kg} \mathrm{~N} / \mathrm{ha}$ instead of $120 \mathrm{~kg}$ $\mathrm{N} / \mathrm{ha}$ and $160 \mathrm{~kg} \mathrm{~N} / \mathrm{ha}$ may be opted for. However, there is need to carry out the study across the other Natural Regions of Zimbabwe under dry and/or irrigated 
conditions to determine effects of different environmental influences which may include soil type and $\mathrm{pH}$.

\section{Conflicts of Interest}

The authors declare no conflicts of interest regarding the publication of this paper.

\section{References}

[1] Xiao, P. (2002) Modern Chinese Materia Media, Vol. 3. Chemical Industry Press, Beijing.

[2] Yang, S., Roberts, M.F. and Phillipson, D. (1989) Qinghaosu Anti-Malarial Coordinating Research Group. Methoxylated Flavones and Coumarins from Artemisia annua. Phytochemistry, 28, 1509-1511. https://doi.org/10.1016/S0031-9422(00)97776-8

[3] Simon, J., Park, C., et al. (2005) Artemisia annua, the Anti-Malarial: From Botany and Biology, through Chemistry and Pharmacology to Production, Processing and Post-Harvest Handling Agriculture and Natural Plant Products Program, Rutgers University. Essential Oil Conference, Stellenbosch.

[4] Ferreira, J.F.S., Simon, J.E. and Janick, J. (1997) Artemisia annua: Botany, Horticulture and Pharmacology. In: Janick, J., Ed., Horticultural Reviews, John Wiley \& Sons, Hoboken, Vol. 19, 319-371. https://doi.org/10.1002/9780470650622.ch6

[5] Wright, C.W. (2002) Artemisia. Medicinal and Aromatic Plants-Industrial Profiles. Taylor \& Francis, London.

[6] Simon, J.E. (1990) Artemisia annua L. A Promising Aromatic and Medicinal. In: Janick, J. and Simon, J.E., Eds., Advances in New Crops, Timber Press, Portland, 522-526.

[7] Enserink, M. (2005) Source of New Hope against Malaria Is in Short Supply. Science, 307, 33. https://doi.org/10.1126/science.307.5706.33

[8] Ferreira, J.F.S., Simon, J.E. and Janick, J. (2005) Cultivation and Genetics of Artemisia annua L. for Increased Production of Anti-Malarial Artemisinin. Plant Genetic Resources, 3, 206-229. https://doi.org/10.1079/PGR200585

[9] WHO (2010) Guidelines for the Treatment of Malaria. 2nd Edition, World Health Organisation, Geneva.

[10] WHO (2000) The Use of Antimalarial Drugs: Report of a WHO Informal Consultation 13-17 November 2000. WHO/CDS/RBM, Geneva, 33.

[11] Verdrager, J. (1986) Epidemiology of the Emergence and Spread of Drug-Resistant Falciparum Malaria in South East Asia and Australasia. Journal of Tropical Medicine and Hygiene, 89, 277-289.

[12] Jung, M. (2004) Recent Advances in Artemisinin and Its Derivatives as Anti-Malarial and Anti-Tumor Agents. Current Medical Chemistry, 11, 1265-1284. https://doi.org/10.2174/0929867043365233

[13] Ferreira, J.F.S. and Janick, J. (1995) Floral Morphology of Artemisa annua L. with Special Reference to Trichomes. International Journal of Plant Sciences, 156, 807-815. https://doi.org/10.1086/297304

[14] Esteban, M.D., Collado, I.G., Macias, F.A., Massanet, G.M. and Luis, F.R. (1986) Flavanoids from Artemisia lanata. Phytochemistry, 25, 1502-1504.

https://doi.org/10.1016/S0031-9422(00)81325-4 
[15] Delabays, N., Simonnet, X. and Gaudin, M. (2001) The Genetics of Artemisinin Content in Artemisa annua L. and the Breeding of High Yielding Cultivars. Current Medical Chemistry, 8, 1795-1801. https://doi.org/10.2174/0929867013371635

[16] Raeth, K., Taxis, K., Walz, G., et al. (2004) Pharmacokinetic Study of Artemisinin after Oral Intake of a Traditional Preparation of Artemisia annua (Annual Wormwood). The American Journal of Tropical Medicine and Hygiene, 70, 128-132. https://doi.org/10.4269/ajtmh.2004.70.128

[17] Noorden, R.V. (2010) Demand for Malaria Drug Soars. Nature, 466, 672-673. https://doi.org/10.1038/466672a

[18] Kindermans, J.M. (2007) Ensuring Sustained ACT Production and Reliable Artemisinin Supply. Malaria Journal, 6, 125. https://doi.org/10.1186/1475-2875-6-125

[19] Rengel, Z. (1998) Nutrient Use in Crop Production. Taylor \& Francis Ltd., Abingdon.

[20] Strong, W.M. (1995) Nitrogen Fertilization of Upland Crops in Nitrogen Fertilization. Marcel Dekker, New York.

[21] Fabian, A. and Germishuizen, G. (1997) Wild Flowers of Northern South Africa Cape Town, South Africa. Fernwood Press, Cape Town.

[22] ALNP African Laboratory for Natural Products (2001) Medicinal and Aromatic Plants. ICS-UNIDO, Addis Ababa.

[23] DuPreez, R. (2005) Herbs for the Garden. ARC Institute for Tropical and Sub-Tropical Crop, Nelspruit.

[24] Bumb, B.L. (1995) World Nitrogen Supply and Demand, an Overview in Nitrogen Fertilization in the Environment. P.E. Bacon Publishers, New York.

[25] Yawalkar, E. (2002) Manures and Fertilizers. 9th Revised Edition, Agri-Horticultural Publishing House, Nagpur.

[26] Kern, C.C., Friend, A.L., Johnson, J.M.F. and Coleman, M.D. (2004) Fine Root Dynamics in a Developing Populus deltoides Plantation. Tree Physiology, 24, 651-660. https://doi.org/10.1093/treephys/24.6.651

[27] Woolfolk, W.T.M. and Friend, A.L. (2003) Growth Response of Cottonwood Roots to Varied $\mathrm{NH}_{4}: \mathrm{NO}_{3}$ Ratios in Enriched Patches. Tree Physiology, 23, 427-432. https://doi.org/10.1093/treephys/23.6.427

[28] López-Bucio, J., Cruz-Ramírez, A. and Herrera-Estella, L. (2003) The Role of Nutrient Availability in Regulating Root Architecture. Current Opinion in Plant Biology, 6, 280-287. https://doi.org/10.1016/S1369-5266(03)00035-9

[29] WHO (2006) World Health Organisation Bulletin: Monograph on Good Agricultural and Collection Practice for Artemisia annua. WHO Library, Geneva. 